\title{
ANALISIS PENGARUH HARGA, KUALITAS PRODUK DAN DESAIN TERHADAP KEPUTUSAN PEMBELIAN KENDARAAN BERMOTOR MEREK HONDA JENIS SKUTERMATIC
}

\author{
Tina Martini \\ STAIN Kudus, Jawa Tengah, Indonesia \\ tina_martin@yahoo.com
}

\begin{abstract}
ANALYSIS OF PRICE EFFECT, PRODUCTS AND DE-SIGN QUALITIES TO BUYING DECISIONS of HONDA SKUTERMATIC MOTORCYCLES. This research is a field of research and using a quantitative approach. While the sample in this study is that consumers / users of motorcycle of Honda skutermatic by distributing questionnaires as much as 75 respondents. Sampling used techniques sampling insidenta. The analytical method used is multiple linear regression method and using $t$ - test with a significance level $a=5 \%$. Results from this study show that first: the price has an influence on the purchase decisions of Honda types of skutermatic vehicles on public from the kudus District, it is proved by $t$ - test to show the price $t$ is greater than $t$ table $(4,140>1,992)$ with 75 df and probability value of 0.000 is below the 5\% level of significance. Secondly, the quality has a negative influence on purchasing decisions and it is evidenced by the results of the t value of 1.157 and $t$ table amounted to 1.992, so the t-count is smaller than t-table (1.157 <1.992) of df 75 with a P value of 0.251. And third, the design has an influence on the purchase decisions of Honda types of skutermatic vehicles in Kudus society. This is evidenced from the t test results showing that for the design of $t$ is greater than $t$ table (3.073>
\end{abstract}


1.992), while the value of the $P$ value of 0.003 which is above $5 \%$ Alpha.

Keywords: Price, Quality, Design, Purchase Decision.

\begin{abstract}
Abstrak
Penelitian ini merupakan jenis penelitian field reserch dan menggunakan pendekatan kuantitatif. Sedangkan sampel dalam penelitian ini adalab konsumen/pemakai kendaraan bermotor merek Honda jenis skutermatic dengan menyebarkan kuesioner sebanyak 75 responden. Pengambilan sampel menggunakan tehnik sampling insidenta. Metode analisis yang digunakan adalab metode regresi linier berganda dan menggunakan uji - $t$ dengan taraf signifikansi $a=5 \%$. Hasil dari penelitian ini menunjukean babwa pertama: harga mempunyai pengaruh terhadap keputusan pembelian kendaraan bermotor merek. Honda jenis skutermatic pada masyarakat Kabupaten Kudus dibuktikan dari hasil uji- t untuk harga menunjukan t hitung lebih besar dari nilai t tabel $(4,140>1,992)$ dengan df 75 dan nilai probabilitas sebesar 0.000 yaitu berada dibawah 5\% dari tingkat signifikan. Kedua, kualitas mempunyai pengarub negatif terhadap keputusan pembelian dibuktikan dengan hasil nilai t hitung sebesar 1,157 dan t tabel sebesar 1,992, sehingga t-hitung lebih kecil dari t-tabel $(1,157<1,992)$ dari df 75 dengan nilai $P$ value 0,251. Dan yang ketiga, desain mempunyai pengaruh terhadap keputusan pembelian kendaraan bermotor merek. Honda jenis skutermatic pada masyarakat Kabupaten Kudus. Ini dibuktikan dari hasil uji t yaitu untuk desain menunjukan $t$ bitung lebih besar dari nilai $t$ tabel (3,073 > 1,992), sedangkean nilai $P$ value 0,003 yang berada diatas Alpha 5\%.
\end{abstract}

Kata Kunci : Harga, Kualitas, Desain, Keputusan Pembelian

\title{
A. Pendahuluan
}

Dalam menghadapi pasar bebas yang ditandai dengan perkembangan usaha yang dinamis dan penuh persaingan maka perusahaan harus melakukan kegiatan pemasaran yang tepat sasaran dan perubahan orientasi terhadap cara melayani konsumennya, menangani pesaing, dan mengeluarkan produk. Dengan adanya persaingan yang semakin ketat maka kegiatan 
pemasaran yang dilakukan oleh perusahaan harus semakin ditingkatkan dan lebih diarahkan agar tepat sasaran begitu juga dengan pelayanan terhadap konsumen harus lebih diutamakan karena pada saat ini sebagian besar konsumen lebih selektif terhadap apa yang mereka terima dan harapkan dari sebuah produk.

Dengan adanya dasar seperti ini, maka sulit bagi suatu perusahaan untuk melayani seluruh pasar yang berbeda jenis dan sifatnya, maka perusahaan harus berusaha untuk mengisi segmen pasar yang kebutuhan dan keinginannya belum dapat dipenuhi oleh produk yang tersedia.

Kehidupan masyarakat modern saat ini turut mempengaruhi pola perilaku masyarakat dalam pembelian. Kehidupan modern seringkali diidentikkan dengan gaya hidup yang selalu mengikuti trend atau perkembangan jaman. Perkembangan teknologi yang semakin pesat seiring dengan peningkatan peradaban manusia menyebabkan persaingan yang semakin ketat. Dengan adanya persaingan mendorong setiap perusahaan untuk menciptakan keunggulan. Syarat yang harus di penuhi oleh suatu perusahaan agar dapat sukses dalam persaingan adalah berusaha mencapai tujuan untuk menciptakan dan mempertahankan pelanggan. Agar tujuan tersebut tercapai, maka setiap perusahaan harus berupaya menghasilkan dan menyampaikan barang dan jasa yang diinginkan konsumen dengan harga yang pantas (reasonable). Dengan demikian setiap perusahaan harus mampu memahami perilaku konsumen pada pasar sasarannya, karena kelangsungan hidup perusahaan tersebut sebagai organisasi yang berusaha memenuhi kebutuhan dan keinginan para konsumen sangat tergantung pada perilaku konsumennya.

Keadaan tersebut menuntut perusahaan untuk semakin inovatif dalam mengeluarkan produk yang disukai konsumen, tanpa inovasi produk suatu perusahaan bisa tenggelam dalam persaingan dengan produk-produk lain yang semakin memenuhi pasar. Memahami konsumen adalah elemen penting 
dalam pengembangan strategi pemasaran, perilaku konsumen memberikan informasi mengenai berbagai fakta tentang perilaku berbelanja, misalnya dalam melakukan pembelian suatu produk para konsumen memiliki berbagai sikap yang berbeda-beda dalam memandang berbagai atribut produk yang dianggap relevan dan penting. ${ }^{1}$

Berdasarkan beberapa penelitian sejenis yang menggunakan atribut produk diantaranya hasil penelitian yang dilakukan oleh Prosetyo Budi Kurniawan pada tahun 2005 mengenai atribut persepsi yang mempengaruhi keputusan konsumen pada Honda Karisma menggunakan 5 atribut yaitu produk, merek, harga, iklan, dan pelayanan purna jual.

Sedangkan penelitian yang dilakukan oleh Aji Setyobudi pada tahun 2009 mengenai analisis pengaruh atribut produk terhadap keputusan pembelian Suzuki Smash yang menggunakan 4 atribut produk yaitu harga, merek, kualitas, dan ciri/ keistimewaan. Setiap atribut produk memiliki peran yang berbeda terhadap pengambilan keputusan pembelian. Perilaku pembelian seseorang dapat dikatakan sesuatu yang unik, karena preferensi dan sikap terhadap obyek setiap orang berbeda. Selain itu konsumen berasal dari beberapa segmen, sehingga apa yang diinginkan dan dibutuhkan juga berbeda. Masih terdapat banyak faktor yang berpengaruh terhadap keputusan pembelian. Produsen perlu memahami perilaku konsumen terhadap produk atau merek yang ada di pasar, selanjutnya perlu dilakukan berbagai cara untuk membuat konsumen tertarik terhadap produk yang dihasilkan.

Pengembangkan model perilaku konsumen dengan menetapkan tiga faktor yang berpengaruh terhadap perilaku konsumen. Faktor pertama yang berpengaruh pada konsumen adalah stimuli. Stimuli menunjukkan penerimaan informasi oleh konsumen dan pemprosesan informasi terjadi saat konsumen mengevaluasi informasi dari periklanan, teman atau dari

${ }^{1}$ Philip Kotler, Manajemen Pemasaran Analisis Perencanaan Implementasi dan Kontrol, Jilid 1 (Jakarta: Prehalindo, 1997), hlm. 23. 
pengalaman sendiri. Pengaruh kedua berasal dari karakteristik pribadi konsumen meliputi persepsi, sikap, manfaat serta karakteristik konsumen (demografi, kepribadian, gaya hidup). Pengaruh yang ketiga respon konsumen yaitu hasil akhir dari proses keputusan konsumen dan suatu pertimbangan yang menyeluruh dari semua faktor diatas. ${ }^{2}$

Penelitian mengenai faktor-faktor yang mempengaruhi proses atau keputusan pembelian telah banyak dilakukan. Melalui riset ini akan dianalisis mengenai pengaruh harga, kualitas dan desain produk terhadap keputusan pembelian kendaraan bermotor merek Honda jenis skutermatic. Ketertarikan pemilihan jenis skutermatic tersebut karena produk kendaraan bermotor jenis skutermatic semakin diminati tidak hanya dikalangan wanita Indonesia saja, tetapi juga seluruh kalangan mulai dari anak muda sampai orang tua.

\section{B. Pembahasan}

\section{Pengertian Pemasaran}

Pemasaran dapat diartikan sebagai suatu kegiatan yang mengusahakan agar produk yang dipasarkannya itu dapat diterima dan disenangi oleh pasar. ${ }^{3}$ Sedangkan menurut Kotler ${ }^{4}$, Pemasaran adalah proses sosial yang didalamnya individu dan kelompok mendapatkan apa yang mereka butuhkan dan inginkan dengan menciptakan, menawarkan dan secara bebas mempertukarkan produk yang bernilai dengan pihak lain. Sedangkan menurut Swastha Pemasaran adalah keseluruhan dari kegiatan-kegiatan usaha yang ditujukan untuk merencanakan, menentukan harga, mempromosikan dan mendistribusikan barang dan jasa yang memuaskan kebutuhan baik kepada pembeli yang ada maupun

\footnotetext{
${ }^{2}$ Ibid., hlm. 25.

${ }^{3}$ Indrio Gitosudarmo, Manajemen Pemasaran (Yogjakarta: BPFE, 1997), hlm. 43 .

${ }^{4}$ Kotler, Philip, Manajemen Pemasaran Analisis, hlm. 27.
} 
pembeli potensial. ${ }^{5}$ Dari definisi di atas dapat disimpulkan bahwa pemasaran adalah proses yang mencakup analisis, perencanaan, pelaksanaan dan pengawasan, juga mencakup barang, jasa serta gagasan, berdasarkan pertukaran dan tujuannya adalah memberikan kepuasan bagi pihak yang terlibat.

Pengertian pemasaran dari kedua pendapat diatas menerangkan bahwa kegiatan pemasaran mencakup ruang lingkup kegiatan yang sangat luas yang dimulai dari menetukan kebutuhan konsumen dan diakhiri dengan kepuasan konsumen. Dengan kata lain kegiatan pemasaran bermula dan berakhir pada konsumen.

\section{Konsep pemasaran}

Marketing Concept menganut falsafah bahwa strategi pemasaran bergantung pada pemahaman lebih baik bagi konsumen. Bagi perusahaan yang memahami akan arti pentingnya pemasaran dalam pencapaian sukses usahanya akan mengetahui adanya falsafah, di dalam falsafah inilah yang disebut konsep pemasaran. Bagi perusahaan yang berorientasi pada konsumen (pasar), maka kegiatan pemasaran akan bermula dan berakhir pada konsumen. Artinya dimulai dari menetukan apa yang diinginkan konsumen dan diakhiri dengan kepuasan konsumen.

Pemuasan kebutuhan konsumen merupakan syarat mutlak bagi kelangsungan hidup perusahaan seperti yang tercermin dalam konsep pemasaran yang dikemukakan oleh Dharmmesta ${ }^{6}$ bahwa konsep pemasaran adalah suatu falsafah bisnis yang menyatakan bahwa kepuasan kebutuhan konsumen merupakan syarat ekonomi dan social bagi kelangsungan hidup perusahaan. Sedangkan menurut Kotler menerangkan bahwa konsep pemasaran adalah kunci untuk mencapai tujuan organisasional yang ditetapkan oleh perusahaan tersebut menjadi efektif dibandingkan para pesaing

5 Swastha, Basu dan Handoko, Hani, Manajemen Pemasaran: Analisa Perilaku Konsumen (Yogyakarta: BPFE, 2000), hlm. 76.

${ }^{6}$ Irawan. Manajemen Pemasaran Modern (Yogyakarta: Liberti,2003), hlm. 32 . 
dalam menciptakan, menyerahkan dan mengkomunikasikan nilai pelanggan kepada pasar sasaran yang terpilih. Konsep pemasaran terdiri dari: Segmentasi Pasar (Segmentation), Menetapkan pasar sasaran (Targeting) dan Menentukan posisi pasar (Positioning). ${ }^{7}$

\section{Bauran pemasaran (marketing mix)}

Pemasaran mempunyai fungsi yang amat penting dalam mencapai keberhasilan perusahaan. Dalam mencapai keberhasilan pemasaran, setiap perusahaan perlu menyusun strategi pemasaran yang efektif dengan mengkombinasikan elemen - elemen dalam bauran pemasaran. Dalam bauran pemasaran (marketing mix) terdapat variabel - variabel yang saling mendukung satu dengan yang lainnya yang kemudian oleh perusahaan digabungkan untuk memperoleh tanggapan - tanggapan yang diinginkan didalam pasar sasaran.

Strategi pemasaran memerlukan keputusan - keputusan dari manajemen tentang elemen - elemen marketing mix perusahaan yaitu keputusan - keputusan dibidang perencanaan produk, penetapan harga, saluran distribusi serta promosi ${ }^{8}$ Marketing mix atau bauran pemasaran adalah kombinasi dari empat variabel yaitu produk, struktur harga, kegiatan promosi, dan sistem distribusi. Perpaduan antara empat macam hal tersebut merupakan senjata bagi pengusaha dalam memasarkan produknya atau melayani konsumennya. Keempat unsur bauran pemasaran tersebut saling berhubungan dan berpengaruh satu sama lain, sehingga harus diupayakan untuk menghasilkan suatu kebijakan pemasaran yang mengarah kepada layanan efektif dan kepuasan konsumen.

\footnotetext{
${ }^{7}$ Kotler Philip, Manajemen Pemasaran Analisis, hlm. 28.

${ }^{8}$ Dharmmesta dan Irawan, Manajemen Pemasaran Modern (Yogyakarta: Liberti,2001), hlm. 67.
} 


\section{Keputusan Pembelian}

Keputusan membeli merupakan salah satu komponen utama dari perilaku konsumen. Keputusan pembelian konsumen merupakan tahap demi tahap yang digunakan konsumen ketika membeli barang dan jasa. ${ }^{9}$ Keputusan pembelian adalah sebuah pendekatan penyelesaian masalah pada kegiatan manusia untuk membeli suatu barang atau jasa dalam memenuhi keinginan dan kebutuhannya yang terdiri dari pengenalan kebutuhan dan keinginan, pencarian informasi, evaluasi terhadap alternatif pembelian, keputusan pembelian dan tingkah laku setelah pembelian. ${ }^{10}$

Menurut Basu Swastha perilaku konsumen dapat diartikan sebagai suatu kegiatan-kegiatan individu yang secara langsung terlibat dalam mendapatkan serta menggunakan barang-barang dan jasa-jasa, termasuk di dalamnya proses pengambilan keputusan pada persiapan dan penerapan kegiatan Perilaku konsumen akan menentukan proses pengambilan keputusan dalam pembelian mereka. Proses tersebut merupakan sebuah pendekatan penyelesaian masalah yang terdiri atas beberapa tahap. Seluruh proses tersebut tidak selalu dilakukan oleh konsumen dalam pembeliannya. ${ }^{11}$ Pada umunya konsumen akan lebih mudah mengambil keputusan dalam pembelian ulang atau pembelian yang sifatnya terus menerus terhadap produk yang sama.

Hsu dan Chang mengemukakan indikator untuk mengukur keputusan pembelian sebagai berikut; kebutuhan dan keinginan akan suatu produk, keinginan mencoba, kemantapan akan kualitas suatu produk, keputusan pembelian ulang. ${ }^{12}$ Sedangkan Sweeney menyatakan bahwa indikator keputusan pembelian adalah buy or not buy berhubungan dengan keyakinan dalam membeli dan would

\footnotetext{
${ }^{9}$ Ibid., hlm. 15.

10 Swastha Basu dan Handoko, Hani, Manajemen Pemasaran: Analisa
} Perilaku Konsumen, Edisi pertama (Yogyakarta: BPFE, 2000), hlm. 65.

${ }^{11}$ Swastha Basu dan Handoko, Hani, Manajemen Pemasaran, hlm. 34.

${ }^{12}$ Ibid., hlm. 52. 
not expect any problem yaitu harapan untuk tidak mendapatkan masalah atau resiko, serta pertimbangan untuk mendapatkan manfaat dari produk. ${ }^{13}$

\section{Harga}

Harga adalah jumlah uang ditambah beberapa produk apabila memungkinkan) yang dibutuhkan untuk mendapatkan sejumlah kombinasi dari produk dan pelayanannya. ${ }^{14}$ Berdasarkan sudut pandang pemasaran harga merupakan satuan moneter atau ukuran lainnya termasuk barang dan jasa lainnya) yang ditukarkan dengan memperoleh hak kepemilikan suatu barang atau jasa. ${ }^{15}$ Kotler menyatakan bahwa harga adalah salah satu bauran pemasaran yang menghasilkan pendapatan, unsur lainnya menghasilkan biaya. ${ }^{16}$ Hal ini juga dibenarkan oleh Ma'ruf, menurut Ma'ruf harga adalah satu-satunya unsur dalam berbagai unsur bauran pemasaran yang akan mendatangkan laba bagi peritel, sedangkan unsur-unsur yang lainnya menghabiskan biaya. Jadi sangat wajar jika harga mempunyai pengaruh yang tidak kecil terhadap pendapatan dan laba bersih perusahaan. ${ }^{17}$ Harga adalah unsur bauran pemasaran yang paling mudah disesuaikan, ciri-ciri produk, saluran distribusi, bahkan promosi membutuhkan lebih banyak waktu. Harga juga mengkomunikasikan posisi nilai yang dimaksudkan perusahaan tersebut kepada pasar tentang produk dan mereknya. Dalam hal ini harga merupakan suatu cara bagi seorang penjual untuk membedakan penawarannya dari pesaing. Sehingga penetapan harga dapat dipertimbangkan sebagai bagian dari fungsi diferensiasi barang dalam pemasaran. Pada umumnya penjual mempunyai beberapa tujuan dalam penetapan harga produknya.

\footnotetext{
${ }^{13}$ Ibid., hlm. 54.

${ }^{14}$ Ibid., hlm. 241.

${ }^{15}$ Fandy Tjiptono, Strategi Pemasaran (Yogyakarta: Andi Offset, 1997),
} hlm. 44.

${ }^{16}$ Kotler Philip, Manajemen Pemasaran Analisis, hlm. 32.

${ }^{17}$ Ibid., hlm. 43. 
Sedangkan Harga menurut Husain Umar adalah “sejumlah nilai yang ditukarkan konsumen dengan manfaat dari memiliki atau menggunakan produk atau jasa yang nilainya ditetapkan oleh pembeli dan penjual melalui tawar menawar, atau ditetapkan oleh penjual untuk satu harga yang sama terhadap semua pembeli”. Harga merupakan faktor penentu yang mempengaruhi pilihan pembelian, hal ini masih menjadi kenyataan di negara-negara dunia ketiga, di kalangan kelompok-kelompok sosial yang miskin, serta pada bahan-bahan pokok sehari-hari. Namun dalam dasawarsa terakhir ini, faktor-faktor lain selain harga telah beralih menjadi relatif lebih penting dalam proses pembelian. ${ }^{18}$

\section{Kualitas produk}

Persaingan merek yang tajam belakangan ini memaksa para marketer untuk memberikan daya tarik yang lebih baik daripada pesaingnya. Maklum, adanya merek membuat konsumen diuntungkan. Konsumen memilih suatu merek adalah kualitas produk. Kualitas produk tidak diragukan lagi mempengaruhi keputusan pembelian konsumen. Kualitas produk yang dapat diterima adalah elemen utama yang mempengaruhi perilaku pembelian konsumen. Garvin telah mengungkapkan adanya delapan dimensi dari kualitas dan produk. ${ }^{19}$

\section{Desain}

Menurut Stanton Desain produk merupakan salah satu aspek pembentuk citra produk. Perusahaan juga makin menyadari pentingnya nilai pemasaran dari desain produk, terutama desain penampilannya. Dua faktor yang menyangkut desain produk adalah warna dan kualitas produk. Pemilihan warna yang tepat merupakan keuntungan tersendiri bagi pemasaran suatu produk. Ketepatan manajemen dalam memilih warna apa yang sesuai serta kapan harus mengganti warna produk. ${ }^{20}$ Menurut

${ }^{18}$ Husain, Umar Metodelogi Penelitian (Aplikasi dalam Pemasaran) (Jakarta : Gramedia Pustaka Utama, 1997), hlm. 32.

${ }^{19}$ Ibid., hlm. 15.

${ }^{20}$ Stanton Riset Pemasaran dan Perilaku Konsumen (Jakarta : Gramedia 
Kotler Desain produk yang baik dapat menarik perhatian untuk melakukan pembelian, meningkatkan kinerja, mengurangi biaya, dan menyesuaikan nilai terhadap pasar sasaran yang diinginkan. ${ }^{21}$ juga mengungkapkan terdapat 7 parameter desain produk yaitu:

a) Ciri-ciri.

Ciri-ciri adalah karakteristik yang mendukung fungsi dasar produk. Sebagian besar produk dapat ditawarkan dengan beberapa ciri-ciri. Ciri-ciri produk merupakan alat kompetitif untuk produk perusahaan yang terdiferensiasi.

b) Kinerja

Kinerja mengacu kepada tingkat karakteristik utama produk pada saat beroperasi. Pembeli produk-produk mahal biasanya membandingkan kinerja (kenampakan/ prestasi) dari merek-merek yang berbeda.

c) Mutu Kesesuaian

Yang dimaksud dengan penyesuaian adalah tingkat dimana desain produk dan karekteristik operasinya mendekati standar sasaran.

d) Tahan Lama (Durability)

Daya tahan merupakan ukuran waktu operasi yang diharapkan dari suatu produk tertentu.

e) Taban Uji (Reliabilitas)

Reliabilitas adalah ukuran kemungkinan bahwa suatu produk tidak akan berfungsi salah atau rusak dalam suatu periode waktu tertentu. Pembeli rela membayar lebih untuk produk-produk dengan reputasi reliabilatas yang lebih tinggi.

f) Kemudaban Perbaikan (Repairability)

Pustaka Utama dan Jakarta Business Research Center, 2000), hlm. 56.

${ }^{21}$ Kotler Philip, Manajemen Pemasaran Analisis, hlm. 33. 
Kemudahan perbaikan adalah suatu ukuran kemudahan perbaikan suatu produk yag mengalami kegagalan fungsi atau kerusakan-kerusakan.

g) Model (Style)

Model menggambarkan seberapa jauh suatu produk tampak dan berkenan bagi konsumen. Model memberi keunggulan ciri kekhususan produk yang sulit untuk ditiru. Aspek Desain dalam kegiatan pemasaran merupakan salah satu pembentuk daya tarik terhadap suatu produk. Desain dapat membentuk atau memberikan atribut pada suatu produk, sehingga dapat menjadi ciri khas pada merek suatu produk. ${ }^{22}$ Ciri khas dari suatu produk tersebut pada akhirnya akan dapat membedakannya dengan produk-produk sejenis merek lain dari pesaing digambarkan sebagai berikut :

Kerangka Pemikiran Teoritis

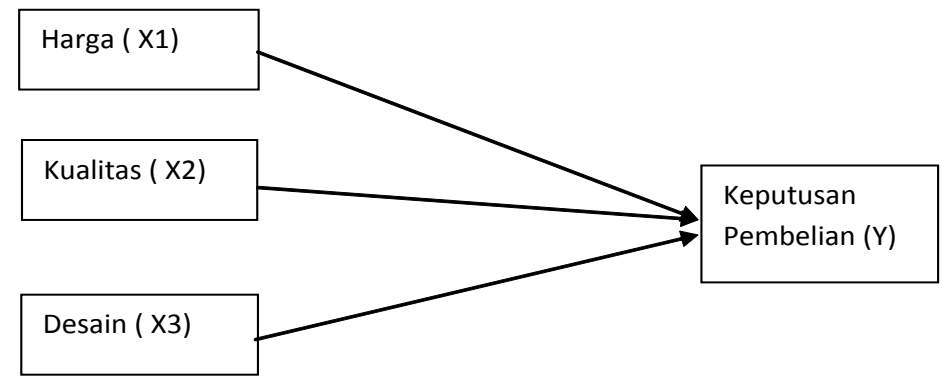

\section{Metodologi}

Jenis penelitian ini merupakan jenis penelitian lapangan / Field Research. Dalam penelitian ini yang akan diamati adalah pengaruh harga, kualitas produk dan desain terhadap keputusan pembelian kendaraan bermotor merek Honda jenis skutermatic pada masyarakat kabupaten Kudus. Pada penelitian ini menggunakan pendekatan kuantitatif. Responden yang menjadi sasaran peneliti adalah konsumen kendaraan bermotor merek Honda jenis skutermatic. Dalam penelitian ini peneliti menyebarkan sebanyak

${ }^{22}$ Kotler Philip, Manajemen Pemasaran Analisis, hlm. 29. 
Analisis Pengaruh Harga, Kualitas produk dan Desain....

85 kuesioner. Tetapi setelah diolah ternyata terdapat 5 kuesioner yang tidak valid / tidak dapat diolah dan 5 kuesioner yang tidak kembali. Jadi data yang dapat diolah dalam penelitian ini sebanyak 75 kuesioner.

Analisis data yang dilakukan untuk pengolahan data penelitian adalah menggunakan pendekatan statistk regresi model berganda menggunakan program SPSS (Statistical Package For Sosial Science) 18.0 for windows. statistik. Uji partial (uji- t) yang digunakan untuk menguji besarnya pengaruh dari variabel independen secara parsial atau individual dengan variabel dependen.

\section{Validitas dan Reliabilitas}

Penelitian ini menunjukkan bahwa besarnya df dapat dihitung 75-2 atau df 73 dengan alpha 0.05 didapat $r$ tabel 0,374 Jika $\mathrm{r}$ hitung (untuk $\mathrm{r}$ tiap butir dapat dilihat pada kolom Corrected Item Total Corelation) lebih besar dari $\mathrm{r}$ tabel dan nilai $\mathrm{r}$ positif, maka butir atau pertanyaan tersebut dikatakan valid. Hasil analisis validitas dapat dilihat pada tabel berikut ini.

Tabel 01 Hasil Uji Validitas Instrumen

\begin{tabular}{ccccc}
\hline Variabel & Item & $\begin{array}{c}\text { Corected Item- } \\
\text { Total Correlation } \\
\text { (r hitung) }\end{array}$ & r tabel & Keterangan \\
\hline \multirow{5}{*}{ Harga (X1) } & Q1 & 0,875 & 0,191 & Valid \\
& Q2 & 0,693 & 0,191 & Valid \\
& Q3 & 1,092 & 0,191 & Valid \\
& Q4 & 0,820 & 0,191 & Valid \\
& Q5 & 0,657 & 0,191 & Valid \\
\hline \multirow{5}{*}{ Kualitas } & Q1 & 0,574 & 0,191 & Valid \\
& Q2 & 0,706 & 0,191 & Valid \\
& Q3 & 0,759 & 0,191 & Valid \\
& Q4 & 0,567 & 0,191 & Valid \\
& Q5 & 0,600 & 0,191 & Valid \\
& Q6 & 0,776 & 0,191 & Valid \\
& Q7 & 0,701 & 0,191 & Valid \\
& Q8 & 0,749 & 0,191 & Valid \\
\hline
\end{tabular}




\begin{tabular}{ccccc}
\hline \multirow{2}{*}{ Desain (X3) } & Q1 & 0,693 & 0,191 & Valid \\
& Q2 & 0,492 & 0,191 & Valid \\
& Q3 & 0,521 & 0,191 & Valid \\
Keputusan & Q1 & 0,759 & 0,191 & Valid \\
Pembelian (Y) & Q3 & 0,847 & 0,191 & Valid \\
& Q4 & 0,653 & 0,191 & Valid \\
& 0,592 & 0,191 & Valid
\end{tabular}

Adapun hasil pengujian reliabilitas dapat dilihat pada table berikut :

Tabel 02 Hasil Uji Reliabilitas Instrumen

\begin{tabular}{llll}
\hline Variabel & $\begin{array}{l}\text { Reliability } \\
\text { Coeffiens }\end{array}$ & Alpha & Keterangan \\
\hline Harga (X1) & 5 item & 0,793 & Reliabel \\
\hline Kualitas (X2) & 8 item & 0,855 & Reliabel \\
\hline Desain (X3) & 3 item & 0,684 & Reliabel \\
\hline Keputusan (Y) & 4 item & 0,649 & Reliabel \\
\hline
\end{tabular}

Sumber Data : Data Primer yang diolah, 2012.

Dari tabel di atas dapat diketahui bahwa masing-masing variabel memiliki nilai Cronbach Alpha $>0.60$. Dengan demikian, semua variabel (X1, X2,X3 dan Y) dapat dikatakan reliabel.

\section{Uji Asumsi Klasik}

Berdasarkan hasil pengujian gejala penyimpangan klasik terhadap data penelitian dapat dijelaskan sebagai berikut:

\section{a. Uji Multikolinearitas}

Dari hasil pengujian multikolonieritas yang telah dilakukan diketahui bahwa nilai tolerance variabel X1 sebesar 0,662, variabel X2 sebesar 0,627 dan variabel X3 sebesar 0,806. Dan nilai VIF variabel X1 sebesar 1,511, variabel X2 sebesar 1,596 dan variabel $\mathrm{X} 3$ sebesar 1,240. Hal ini menunjukkan bahwa tidak ada variabel bebas $(X)$ yang memiliki nilai tolerance kurang dari 10\% dan tidak ada variabel bebas $(\mathrm{X})$ yang memiliki nilai VIF lebih dari 10. Jadi dapat disimpulkan bahwa tidak ada multikolonieritas variabel bebas dalam model regresi. 


\section{b. Uji Autokorelasi}

Dari tabel d-statistik Durbin Watson diperoleh nilai dl sebesar 1,54 dan du sebesar 1,71. Karena hasil pengujian DW lebih rendah daripada dl, maka dapat disimpulkan bahwa data penelitian terdapat autokorelasi positif untuk tingkat signifikansi $\alpha=5 \%$. Dapat dilihat pada Tabel 4.8 berikut ini :

Tabel 03 Hasil Uji Autokorelasi

Model Summary ${ }^{\mathrm{b}}$

\begin{tabular}{llllll}
\hline Model & $\mathrm{R}$ & R square & $\begin{array}{l}\text { Adjusted R } \\
\text { Square }\end{array}$ & $\begin{array}{l}\text { Std. Error of } \\
\text { The estimate }\end{array}$ & Durbin-watson \\
\hline 1 & $691^{\mathrm{a}}$ & 477 & 455 & 1,502 & 1,315 \\
\hline
\end{tabular}

a. Predictors: (Constant), DESAIN, HARGA, KUALITAS

b. Dependent Variable: KEPTSAN

\section{c. Uji Heteroskedastitas}

Berdasarkan grafik Scaterplot menunjukkan bahwa ada pola yang tidak jelas, serta ada titik menyebar diatas dan dibawah angka 0 pada sumbu Y. Jadi dapat disimpulkan bahwa tidak terjadi heteroskedastitas pada model regresi.

\section{d. Uji Normalitas}

Berdasarkan Normal Probability Plot menunjukkan bahwa data menyebar disekitar garis diagonal dan mengikuti arah diagonal atau grafik histogram menunjukkan pola distribusi normal maka model regresinya memenuhi asumsi normalitas. Hasil analisis regresi menggunakan bantuan program SPSS menunjukkan bahwa variabel independent mampu menjelaskan variabel dependen sebesar $45,5 \%$ sedangkan yang lain 54,5\%, sisanya menjelaskan variabel lain yang tidak dimasukkan dalam model ini atau tidak diteliti. Dari uji koefisien determinasi tersebut memberikan makna bahwa masih terdapat variabel independen lain yang mempengaruhi keputusan pembelian masyarakat pada produk kendaraan bermotor merek Honda jenis scutermatic di Kabupaten Kudus. Sedangkan hasil t-hitung dijelaskan sebagai berikut ini : 
Pertama, Dari hasil uji t yaitu untuk variabel bebas (harga) menunjukan t-hitung 4,140 dan $\mathrm{P}$ value sebesar 0,000 dari tingkat signifikansi $5 \%$, maka variable pertama menyatakan "Terdapat pengaruh antara harga terhadap keputusan pembelian kendaraan bermotor merek Honda jenis skutermatic pada masyarakat Kabupaten Kudus".

Kedua, hasil perhitungan statistic menunjukkan bahwa kualitas produk memiliki pengaruh negative terhadap keputusan pembelian dengan data yang diterima lewat pengisian kuesioner dari responden, menunjukkan nilai t hitung sebesar 1,157 dan t tabel sebesar 1,992 (1,157 > 1,992). Sedangkan nilai $\mathrm{P}$ value 0,251 yang berada di atas Alpha 5\%. Dengan demikian variable kualitas produk memiliki pengaruh negative terhadap keputusan pembelian.

Ketiga, hasil perhitungan statistic pengaruh desain terhadap keputusan pembelian dengan data yang diterima lewat pengisian kuesioner dari responden, menunjukkan nilai 3,073 dan nilai $P$ value 0,003 yang berada di bawah Alpha 5\%. Dengan demikian variable desain memiliki pengaruh yang signifikan terhadap keputusan pembelian.

Dari uraian diatas dapat dijelaskan dengan persamaan regresinya adalah sebagai berikut:

$$
\begin{aligned}
& \mathrm{Y}=\mathrm{a}+\mathrm{b}_{1} \mathrm{X}_{1}+\mathrm{b}_{2} \mathrm{X}_{2}+\mathrm{b}_{3} \mathrm{X}_{3}+\mathrm{e} \\
& \mathrm{Y}=3,250+0,287 \mathrm{x} 1+0,050 \mathrm{x}_{2}+0,448 \mathrm{x}_{3}+\mathrm{e}
\end{aligned}
$$

Harga merupakan variabel bebas yang berpengaruh signifikan terhadap keputusan pembelian kendaraan bermotor merek Honda jenis skutermatic yang terjadi pada masyarakat Kabupaten Kudus. Penetapan harga oleh penjual akan berpengaruh terhadap perilaku pembelian konsumen, sebab harga yang dapat dijangkau oleh konsumen akan cenderung membuat konsumen melakukan pembelian terhadap produk tersebut. Selain itu, sejalan dengan pendapat dari yang menyatakan bahwa dalam 
Analisis Pengaruh Harga, Kualitas produk dan Desain....

banyak kasus harga merupakan variabel keputusan yang paling penting yang diambil oleh pelanggan karena berbagai alasan. ${ }^{23}$

Kualitas produk merupakan variabel bebas yang berpengaruh negatif terhadap keputusan pembelian kendaraan bermotor merek Honda jenis skutermatic. Hal ini dikarenakan konsumen sudah merasa nyaman dengan produk-produk yang telah dikeluarkan oleh perusahaan Honda sebelumnya, sehingga konsumen mempunyai keyakinan bahwa produk Honda secara otomatis tidak akan mengecewakan konsumen, sehingga factor kualitas tidak mempengaruhi konsumen dalam memutuskan untuk melakukan pembelian kendaraan bermotor merek Honda jenis skutermatic.

Desain merupakan variabel bebas yang berpengaruh signifikan terhadap keputusan pembelian kendaraan bermotor merek Honda jenis skutermatic yang terjadi pada masyarakat Kabupaten Kudus. Sebuah produk yang didesain dengan baik akan mudah dibuat dan didistribusikan. Dari sudut pandang konsumen, produk yang menyenangkan untuk dilihat dan mudah dibuka, dipasang dan dipelajari cara penggunaanya, digunakan, diperbaiki, dan pada akhirnya dibuang. ${ }^{24}$

\section{Simpulan}

Penelitian ini mempunyai tiga tujuan. Tujuan pertama yaitu untuk mengetahui pengaruh harga terhadap keputusan pembelian kendaraan bermotor merek Honda jenis skutermatic, tujuan kedua yaitu untuk mengetahui pengaruh kualitas terhadap keputusan pembelian kendaraan bermotor merek Honda jenis skutermatic, tujuan ketiga yaitu untuk mengetahui pengaruh desain terhadap keputusan pembelian kendaraan bermotor merek Honda jenis skutermatic.

\footnotetext{
${ }^{23}$ Ibid., hlm. 20.

${ }^{24}$ Hasil penelitian ini sejalan dengan penelitian yang telah dilakukan oleh Enrico Adrian Ramadhan 2009.
} 
Dalam menjawab tujuan pertama, hasil penelitian menyatakan bahwa variable harga mempunyai pengaruh terhadap keputusan pembelian kendaraan bermotor merek Honda jenis skutermatic pada masyarakat Kabupaten Kudus. Untuk tujuan yang kedua diperoleh hasil bahwa variable kualitas mempunyai pengaruh negative terhadap keputusan pembelian kendaraan bermotor merek Honda jenis skutermatic pada masyarakat Kabupaten Kudus. Dan untuk tujuan ketiga diperoleh hasil bahwa variable desain mempunyai pengaruh terhadap keputusan pembelian kendaraan bermotor merek Honda jenis skutermatic pada masyarakat Kabupaten Kudus. Berdasarkan sejumlah hasil penelitian tersebut diatas maka direkomendasikan bahwa hendaknya perusahaan menganalisis faktor-faktor yang mempengaruhi keputusan konsumen, terutama mengenai harga, kualitas dan desain serta memahami keputusan pembelian konsumen karena sangat penting bagi setiap perusahaan agar suatu perusahaan dapat meraih competitive advantage di era globalisasi. 


\section{DAFTAR PUSTAKA}

Domodor Gujarati, Ekonomitrika Dasar, Jakarta: Erlangga, 1999.

Fandy Tjiptono, Strategi Pemasaran, Yogyakarta: Andi Offset, 1997.

Gaspert, Vincent, Total Quality Management (TQM), Jakarta : Gramedia Pustaka Utama, 2001

Ghozali, Imam Aplikasi Analisis Multivariate dengan Program SPSS, UNDIP Press, Semarang, 2001.

Gitosudarmo, Indrio, Manajemen Pemasaran, BPFE, Jogjakarta, 1997.

Kotler, Philip, Manajemen Pemasaran Analisis Perencanaan Implementasi Dan Kontrol”, Jilid 1, Jakarta, PT. Prehalindo, 1997.

Sodik, Nur, "Analisis Keberhasilan Persepsi Konsumen Pada Negara Asal Terhadap Konsumen di Kota Surakarta Tahun 2003)", Jurnal Bisnis dan Manajemen, Vol 4, No. 1, Mei 2004 Surakarta, 2004.

Sugiyono, Metode Penelitian Bisnis, Cet. 1, Bandung: Alfabeta, 2002.

Suharsimi Arikunto, Prosedur Penelitian Suatu Pendekatan Praktik, Jakarta: Rineka Cipta, 1993.

Swastha, Basu dan Handoko, Hani, Manajemen Pemasaran: Analisa Perilaku Konsumen, Yogyakarta: BPFE, 2000.

, \& Irawan, Manajemen Pemasaran Modern, Yogyakarta: Liberti, 2003.

Stanton, Riset Pemasaran dan Perilaku Konsumen, Jakarta : Gramedia Pustaka Utama dan Jakarta Business Research Center, 2000. 
Tina Martini

balaman ini bukan sengaja dikosongkan 